Article

\title{
Livelihood Benefits from Post-Earthquake Nature-Based Tourism Development: A Survey of Local Residents in Rural China
}

\author{
Shuwen Liu ${ }^{1}$, Lewis T.O. Cheung ${ }^{2, *}$ (D) Alex Y. Lo ${ }^{3}$ (i) and Wei Fang ${ }^{4}$ \\ 1 School of Arts and Social Sciences, The Open University of Hong Kong, Hong Kong, China; \\ swliu@ouhk.edu.hk \\ 2 Department of Social Sciences, The Education University of Hong Kong, Hong Kong, China \\ 3 Department of Geography, The University of Hong Kong, Hong Kong, China; alexloyh@hku.hk \\ 4 Department of Geography and Resources Management, The Chinese University of Hong Kong, \\ Hong Kong, China; fangwei129@gmail.com \\ * Correspondence: ltocheung@eduhk.hk; Tel.: +852-2948-8908; Fax: +852-2948-8018
}

Received: 1 February 2018; Accepted: 2 March 2018; Published: 5 March 2018

\begin{abstract}
Large-scale tourism development after a natural disaster often leads to substantial changes in the living conditions of local residents. Few studies have examined how these changes are perceived by residents and related to their support to tourism development. We conducted a household survey in Wolong National Nature Reserve, which is a popular nature-based tourist location severely devastated by a catastrophic earthquake in 2008. Structural equation modelling (SEM) was employed to explore the association between residents' expectation of tourism impacts and their willingness to support tourism development. Results indicated that they held high expectations about development and believed that it would be enhance Wolong's economic progress and improve their personal living conditions. Expected economic benefits (EEB) had a significant and positive relationship with the expected improvement of their personal living conditions, but not with their support to tourism development. The latter two variables, however, were associated with each other, suggesting that expected improvement of living conditions mediated between expected benefits and stated support to tourism development. Similar results were not found for resistance and concerns about tourism development. Policy-makers and tourism planners should recognize that public support to tourism development is not necessarily driven directly by expected economic benefits.
\end{abstract}

Keywords: nature-based tourism; post-earthquake; residents' attitudes; supportiveness; Wolong National Nature Reserve

\section{Introduction}

Tourism development has been a strategy of different governments to improve the livelihood of rural residents [1]. However, having tourism development in a world natural heritage site needs special caution, as excessive development may lead to destruction of the natural environment of the heritage. Nature-based tourism development is used as an approach for the government to minimize the negative impacts [2]. Wolong National Nature Reserve has suffered serious destruction after the WenChuan Earthquake in 2008, and the local government intends to revitalize the tourism industry in the form of nature-based tourism that would not cause large scale of negative impacts to the reserve [3].

Post-disaster development is an important topic that has been studied by various scholars in different aspects. Many previous studies focused on the recovery policies and approaches [4-6], planning of reconstruction [7,8], management of infrastructure reconstruction [9], and community resilience $[10,11]$ in natural-hazards-prone countries such as Japan, New Zealand, and Taiwan. Other studies investigated the factors influencing the duration and effectiveness of post-disaster 
recovery $[12,13]$. Some studies have been conducted to explore the recovery of tourism industry after a catastrophic natural disaster. Huang and Min [14] evaluated the rebound of the Taiwan tourism industry after the serious earthquake, and Biran, et al. [15] have investigated tourists' motivations and travel intentions to visit a disaster-hit destination. However, limited research has been done to understand the perception and expectation of the local residents towards post-earthquake tourism development.

Understanding the residents' expected attitudes towards post-earthquake nature-based tourism development is important, as positive attitudes from the local community are essential for tourism development in rural China $[10,16]$. Community support could help to smooth the development process, including land resumption and compensation. Common findings from previous studies suggested that residents' support could be gained if the local residents have positive perceptions of the development, particularly when they believed that they would be benefited through such development [16-18]. However, studies reported that local residents were used to over-expectation of the development projects leading to disappointment.

Local residents in the Wolong National Nature Reserve have been suffering from the catastrophic earthquake, which has affected their livelihoods through tourism [19]. Their income dropped significantly, and they have relied on limited subsidies from the government over the past 8 years. They consider improvement of the financial situation of utmost importance and would like to see the recovery of the nature-based tourism industry in the natural reserve. This situation sets a scene for our study to understand the views of the local residents on the government planning of nature-based tourism development. We aim to investigate the local residents' attitudes on post-quake nature-based tourism development and how their attitudes affect their supportiveness of the development. Very few studies have examined residents' attitudes towards and support for nature-based tourism development after the catastrophic natural disaster in China. Therefore, this important study fills the research gaps in the current literature and offers valuable theoretical insight to understand the essential determinants of local residents' support for post-disaster development. Moreover, this study's findings can also serve as an important reference for the local government to understand the expectations of local residents and their willingness to support development. This information is vital for the local government during the implementation stage of development. Knowing the expectations of the local community could be very useful to allow the local authority to set their targets, which must be fulfilled in order to satisfy local residents' expectations. Local satisfaction regarding nature-based tourism development can help build a harmonious and tourism-friendly community in the future.

\section{Literature Review and Theoretical Underpinning}

An extensive array of studies has been devoted to understanding residents' views of tourism, as negative attitudes among residents can hinder the success and sustainability of tourism destinations [20-23]. To create sound planning for sustainable tourism development, it is vital to understand residents' perceptions of tourism's impact and their level of support for tourism development [24-26].

A number of studies have reported a positive relationship between economic benefits and support for tourism [27]. Employment opportunities, tourism revenues and infrastructure improvement are some of the common motivations for local communities to endorse tourism development [28-30]. Various scholars have reported that a community's economic status and dependency on the tourism industry affect residents' attitudes and responses to tourism development [31-33]; other studies have found a strong connection between personal economic benefits from and support for tourism [18,26,34]. Personal benefits from tourism were found to direct residents' support for tourism development, particularly during times of economic uncertainty, such as during the economic crisis in Greece [24]. However, some residents believe that tourism development can bring unwanted economic pressure. For example, residents in certain destinations were aware of inflation in goods and services as a result of tourism development $[35,36]$. Rising land and housing prices were common if the destination 
became a popular tourist site [36]. In our study areas, local residents of the Wolong National Nature Reserve have been suffering from a significant drop of income due to the earthquake and they are longing for great improvement of their financial situation through development of nature-based tourism. The following hypotheses are therefore developed regarding whether residents' expected economic impacts would influence their support for the nature-based tourism development.

Hypothesis 1. Residents' expected economic benefits positively influence their support for nature-based tourism development.

Hypothesis 2. Residents' expected economic pressure negatively influences their support for nature-based tourism development.

While the importance of tourism's impacts on local economies has been well acknowledged, some researchers have highlighted the need for theoretical foundations that consider both economic and non-economic factors [37]. Social exchange theory (SET) was introduced to the tourism literature by Ap [20] with the assumption that host residents seek tourism development for their community to satisfy economic, social and psychological needs and to improve the community's well-being. The theory suggests that local residents are likely to form their perceptions based on the expected value of the exchange before the actual exchange occurs [20,38]. SET has been widely adopted as a theoretical framework for understanding residents' perceptions of tourism [34,39-41].

However, the implementation of SET has been criticized for moving away from its original conceptualization towards a direction more aligned with economic exchange theory [42]. Other theories have been introduced, including Maslow's theory of human needs [43,44] and Weber's theory of formal and substantive rationality [18], and there has been increasing concern about the quality of life [45-48]. Scholars have indicated that residents may consider 'higher-order' needs, such as the public interest [49], environmental issues [43], or various quality-of-life aspects [50-53], in addition to economic benefits. However, economic benefits are the foundation of higher needs, as residents who feel increasingly satisfied with their economic situation tend to have a higher degree of life satisfaction [54]. This suggests that expected economic benefits may be a contextual factor underpinning other determinants of residents' support to tourism development, such as changes in quality of life.

Based on the prior theoretical and empirical discussion, two meditating constructs, namely the expected improvement of personal living conditions (EIPLC) and the expected deterioration of personal living conditions (EDPLC), will be included in the proposed model; thus, Hypothesis 3 and Hypothesis 4 are proposed:

Hypothesis 3. Residents' perceived economic benefits positively influence their expected improvement in personal living conditions.

Hypothesis 4. Residents' perceived economic pressures positively influence their expected deterioration in personal living conditions.

Once a community becomes a destination, the development impacts of tourism tend to influence local people's quality of life [38]. However, few studies have directly investigated the relationship between residents' perceived improvement in living conditions and their support for tourism in the community $[26,45,55]$. Even less focus has been on tourism-driven changes in living conditions upon post-disaster reconstruction. Existing studies on the impact of tourism offer mixed results. Ko and Steward [56] found that residents' community satisfaction was closely related to perceived positive and negative tourism impacts. Kaplanidou et al. [46] found that, among South African residents, the overall satisfaction with the quality of life had a positive relationship on support for hosting the World Cup as a mega-event The study of Woo et al. also has similar finding [57]. However, other studies have found 
no significant relationship between community satisfaction and tourism attitudes [55]. The following hypotheses are proposed in this study:

Hypothesis 5. Residents' expected improvement in personal living conditions positively influences their support for nature-based tourism development.

Hypothesis 6. Residents' expected deterioration of personal living conditions negatively influences their support for nature-based tourism development.

The above hypotheses and their relationships with each other are outlined in Figure 1 and will be examined using structural equation modelling techniques.

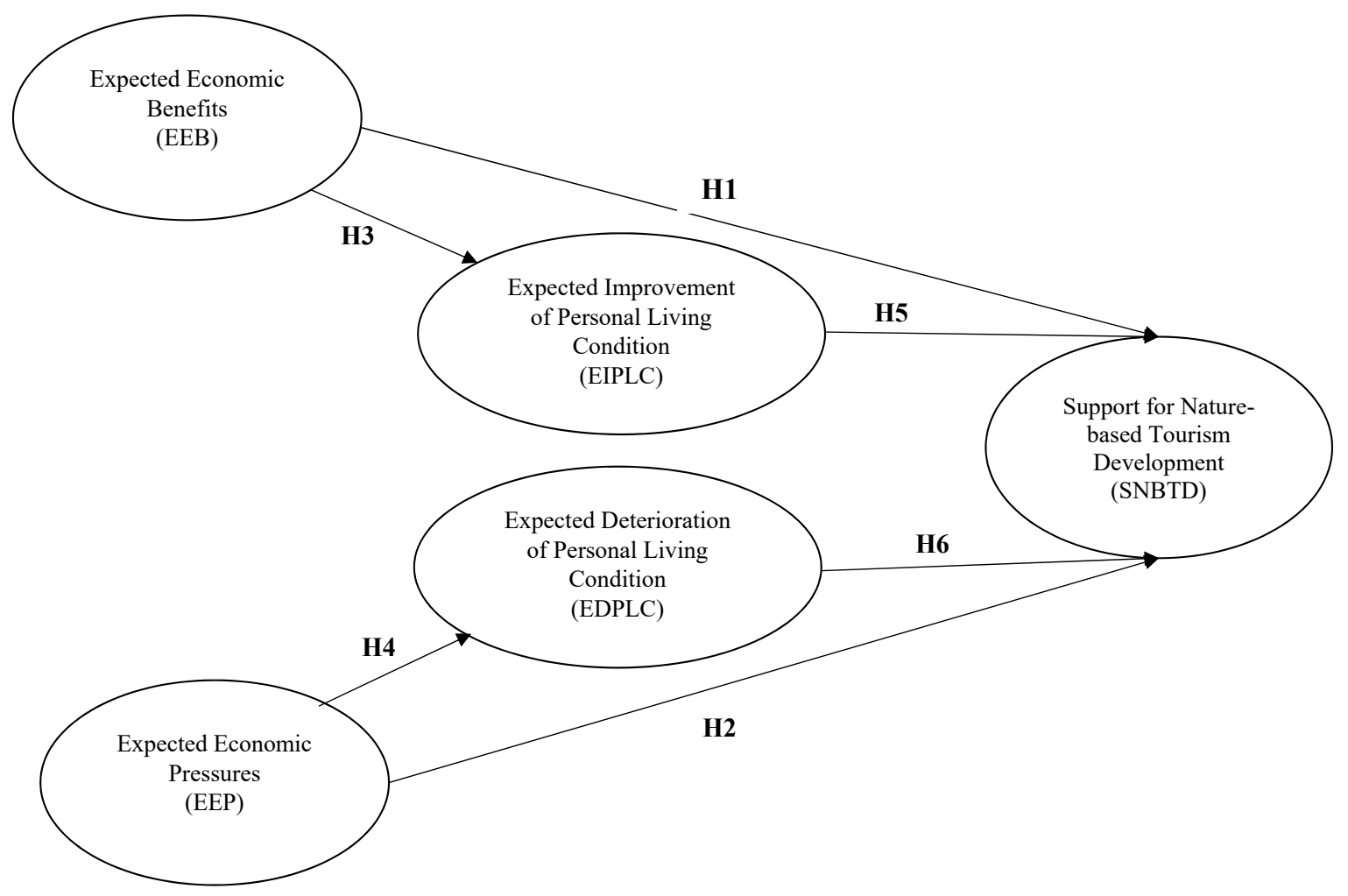

Figure 1. Proposed conceptual model with two proposed mediators for this study.

Based on the previous discussion, local residents' expected attitudes towards the economic impacts of tourism will be assessed in terms of two factors, namely expected economic benefit (EEB) (including the 'promote economic development', 'create employment opportunity' and 'offer income resource' variables) and expected economic pressure (EEP) (including 'uniform economic structure', 'increase estate cost' and 'increase living cost' variables).

This study combined sociocultural and environmental impacts into one variable, defined as tourism's impact on residents' personal living conditions [58,59], which was assessed through two factors, namely EIPLC and EDPLC. The EIPLC factor includes 'enhancement of public facilities in my living place', 'improvement of infrastructure in my living place', 'enhancement of my opportunity for cultural exchange' and 'conservation of the environment surrounding my living place' variables. The question items for assessing EDPLC include 'excessive traffic congestion in my living place', 'conflicts between tourists and residents', 'environmental pollution in my living environment', 'disturbance of my daily life', 'increasing criminal cases in my living community' and 'social evils in my living community' variables. 


\section{Research Methods}

\subsection{Study Area}

Wolong National Nature Reserve was established in 1963 and expanded to 200,000 hectares in 1975 (Figure 2). The reserve is managed by the Wolong Administration Bureau, which is hierarchically structured within two townships, Gengda and Wolong. Approximately 5700 people live inside the reserve, and many of them have relied heavily on the nature-based tourism industry by operating tourism-related small businesses, including farmhouses, retail shops, street vendors, restaurants and hotels. In the 1990s, China's economic reform and "open-door" policy entered a new era, and the country began to receive more international visitors. The Wolong National Nature Reserve was identified as one of the most important tourism resources for international visitors in Sichuan province. The panda breeding program at the China Conservation and Research Centre for the Giant Panda (CCRCGP) publicized the Nature Reserve and attracts over 25,000 visitors annually [60]. The increasing number of visitors accelerated tourism development at the reserve such that the provincial government made funding available for infrastructure improvements, including provincial road construction, to enhance accessibility to the facility. This improved accessibility allowed for the construction of large-scale infrastructure; for example, the first large hotel, 'Wolong Hotel', was built in 1995. During this period, small businesses emerged to provide food and accommodation to visitors, and some local residents began to sell local products to tourists. This marked a change in the local economic structure to a greater reliance on tourism, whereas most local people relied on farming before 2000 .

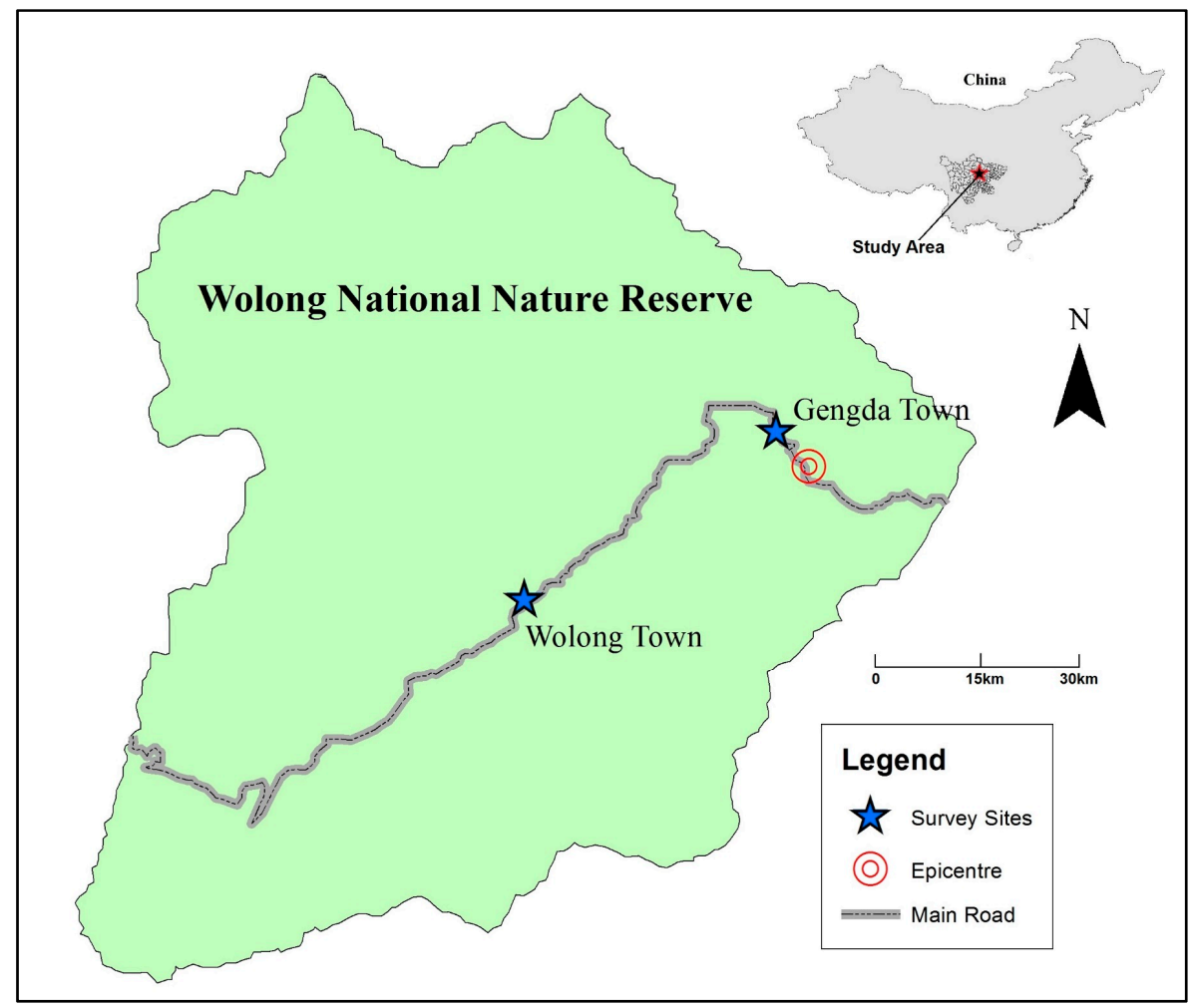

Figure 2. Map of the Wolong National Nature Reserve.

Further improvements in tourism infrastructure were undertaken to increase the capacity of the nature reserve to accommodate more visitors. The visitor number reached its peak in 2007 after the reserve was designated a World Natural Heritage site in 2006. The number of visitors increased from 70,000 in 2003 to 240,000 in 2007 [60]. At that time, the majority of local residents participated in tourism-related businesses, and most of their income came from this industry. 
Before the Wenchuan Earthquake in 2008, tourism was an important income generator for the local residents of the Wolong National Nature Reserve. More than 200,000 tourists visited the nature reserve annually beginning in the year 2000, and over 9 million China Renminbi (CNY) in revenue was generated through the tourism industry, accounting for $33.59 \%$ of the total income of the Wolong Nature Reserve [60]. However, the 2008 earthquake seriously damaged this infrastructure: the earthquake and its associated landslides led to 48 casualties, the disappearance of more than 100 visitors and extensive damage to infrastructure, including the reserve's road network and tourism facilities, and many houses and other buildings collapsed or suffered damage [61]. This natural disaster resulted in a complete halt to tourism, causing a significant drop in local residents' income: their per capita annual net income dropped from an average of CNY 3010 in 2007 to CNY 1860 in 2008 [60].

After the earthquake, Sichuan Province received several billions China Renminbi (CNY) (US\$1 = CNY6.82) in donations for re-construction. Basic infrastructure was rebuilt with funding from different provinces throughout China [62]. The government of the Hong Kong Special Administrative Region (HKSAR) donated HKD 10 billion (US\$128 million) to support the reconstruction of Wolong Town and Gengda Town, which are both located in the reserve. Apart from the construction of basic infrastructure, the donations were used to support the construction of new facilities for the CCRCGP in the Huangcaoping area of Gengda Town. This newly constructed panda research center, which opened in May 2016, has become one of the most important tourism attractions in the Wolong National Nature Reserve. Because the main road was not scheduled for completion until October 2016, the number of tourists able to visit the center and the Nature Reserve as a whole remained limited. However, this will change when the road is complete. Tourism facilities are in standby mode as they await an expected boost in visitors.

\subsection{On-Site Questionnaire Survey}

A structured household questionnaire survey was administered between April 2014 and December 2015 to glean residents' views on post-earthquake nature-based tourism development. We visited Wolong Town and Gengda Town, each of which has administrative villages that were newly constructed after the 2008 earthquake. Wolong and Gengda Towns are situated within the Wolong National Nature Reserve, in close proximity to the epicenter of the earthquake. The two towns are home for more than 4500 local residents in six villages, and each village has approximately $80-100$ households. We invited residents of these villages to participate in the questionnaire survey. Six college students were recruited as research assistants. These student research assistants were fluent in the local dialect and were trained in the procedure and etiquette of questionnaire surveys. Each research assistant was assigned to one village for conducting questionnaire survey in that village. Members of each household aged eighteen or above were invited to complete the questionnaire on a voluntary basis. Research assistants read the questions of the questionnaire aloud, and further explanation was provided to the respondents to ensure their understanding of the question items in light of the low literacy of the local community and the possibility that residents could not read and understand the questions well. The household surveys were conducted on weekdays and weekends to maximize the opportunity to reach those important household members who worked in nearby cities. In order to understand local residents' expectations towards the re-development of tourism, the survey has been conducted before the completion of the main road that the local residents have yet been benefited through increasing number of visitors to the nature reserve. Each respondent took approximately $20 \mathrm{~min}$ to complete the questionnaire, and all respondents received a small gift as a token of appreciation after completion of the questionnaire.

\subsection{Survey Instrument and Data Analysis}

The questionnaire used in this study was divided into three sections (Appendix A). The first section investigated the local residents' expected attitudes towards post-earthquake nature-based tourism development through a total of 16 question items, which were categorized into four groups 
to measure four main proposed constructs of the proposed theoretical models. Three question items, 'A1 nature-based tourism development will promote economic development', 'A3 nature-based tourism development will create employment opportunities', and 'A4 nature-based tourism development will generate tourism income', were included in the EEB construct, while the second construct, EEP, included the three question items: 'A8 nature-based tourism will result in the uniformity of the economic structure', 'A11 nature-based tourism development will increase real estate costs', and 'A12 nature-based tourism development will increase the price of goods and services'. All these items for the EEB and EEP constructs dealt with the generic impacts of tourism development suggested by many previous tourism studies $[27,63]$.

Four question items, namely 'A2 nature-based tourism development will improve the infrastructure in my living place', 'A5 nature-based tourism development will improve public facilities in my living place', 'A6 nature-based tourism development will enhance my opportunity for cultural exchange', and 'A7 nature-based tourism development will contribute to the natural environment of my community', were included in the EIPLC construct, while the EDPLC construct included six question items: 'A9 nature-based tourism development will cause excessive traffic congestion in my living community', 'A13 nature-based tourism will cause conflict between local residents and tourists in my living community', 'A14 nature-based tourism development will increase environmental pollution in my living community', 'A15 nature-based tourism development will disturb my daily life', 'A16 nature-based tourism development will increase crime, robberies and vandalism in my community', and 'A17 nature-based tourism development will cause social problems, including alcoholism and squandering, that will negatively affect my community'. All these items for the EIPLC and EDPLC constructs related to residents' expected personal effects caused by development.

Four question items were included in the second section to measure the local residents' support for post-earthquake nature-based tourism development. These question items included the following: 'B1 I prefer that more tourists visit Wolong', 'B2 I am happy to interact with tourists', 'B3 I prefer that members of my household work in the nature-based tourism industry', and 'B4 I prefer to be involved in the decision making process of nature-based tourism development'. All these items related to their personal willingness to participate in and support development.

The design of these question items was informed by previous studies $[27,63,64]$ and was slightly modified after pre-test on 30 respondents in the community and to fit the local context. The reliability of the proposed four constructs were tested, and the Cronbach's $\alpha$ was between 0.778 and 0.868 , indicating high reliability. All the questionnaire items in the first and second sections were recorded using a five-point Likert scale ranging from 1 (strongly disagree) to 5 (strongly agree). The final section of the questionnaire included question items to understand respondents' socio-economic characteristics, such as gender, age, education level, salary and occupation.

SEM was used in AMOS 21 to test both the theoretical relationships within the proposed models and the overall fit of the model with the questionnaire data. All the parameters were estimated using maximum likelihood estimation. The structural model examined the hypotheses using a path analysis.

\section{Results}

\subsection{Respondent Profiles}

A total of 425 Wolong residents from the six villages were surveyed, and 380 agreed to complete the questionnaire. Only 369 individuals successfully completed the questionnaire, yielding a response rate of $87 \%$. More than half of the respondents were female (54.5\%), with the average income being 1578 Chinese yuan (approximately US $\$ 255$ ). Over $70 \%$ of the respondents had received only junior secondary school education or below, whereas less than $10 \%$ had received post-secondary education. Minority groups were dominant in the population of the Wolong National Nature Reserve. Over 68\% of the respondents were ethnic Tibetans, and only approximately $26 \%$ were of Han origin. As many 
as $70 \%$ of the respondents were engaged in agricultural activities, and less than $30 \%$ participated in non-primary industry (Table 1 ).

Table 1. Respondents' demographic variables.

\begin{tabular}{|c|c|c|c|c|c|}
\hline & $\mathbf{N}$ & $\%$ & & $\mathbf{N}$ & $\%$ \\
\hline Gender & & & \multicolumn{3}{|c|}{ Age } \\
\hline Male & 168 & 45.5 & $15-24$ & 45 & 12.2 \\
\hline Female & 201 & 54.5 & $25-34$ & 77 & 20.9 \\
\hline Ethnic groups & & & $35-44$ & 70 & 19.0 \\
\hline Han & 97 & 26.3 & $45-54$ & 84 & 22.8 \\
\hline Zang & 252 & 68.3 & $55-64$ & 59 & 16.0 \\
\hline Qiang & 19 & 5.2 & Above 65 & 34 & 9.2 \\
\hline Other & 1 & 0.3 & \multicolumn{3}{|c|}{ Occupation } \\
\hline Education & & & Agriculture & 262 & 71.0 \\
\hline Primary school or no education & 160 & 45.5 & Commercial business & 28 & 7.6 \\
\hline Junior secondary school & 119 & 32.2 & Government officer & 3 & 0.8 \\
\hline Senior secondary school & 55 & 14.9 & Teacher & 7 & 1.9 \\
\hline Post-secondary education & 27 & 7.3 & Unemployed & 22 & 6.0 \\
\hline Bachelor degree & 7 & 1.9 & Retired & 0 & 0 \\
\hline Master degree or above & 1 & 0.3 & Others & 47 & 12.8 \\
\hline $\mathrm{N}$ & 369 & & $\mathrm{~N}$ & 369 & \\
\hline
\end{tabular}

\subsection{Residents' Expected Attitudes and Supports}

The descriptive results of the questionnaire survey are listed in Tables 2 and 3 . The results report that the local residents generally held high expectations for re-development of tourism industry in their community. The mean score of those positive constructs-EEB and EIPLC-were 4.58 and 4.33 out of a maximum score of 5 , respectively. The mean score of all the question items for these constructs ranged from 4.10 to 4.66 . The respondents indicated over $90 \%$ agreement with many of the question items: $94.8 \%, 90.8 \%$ and $90.2 \%$ of respondents indicated that they agreed or strongly agreed with question items A1, A3 and A4, respectively, for the EEB construct. Similar to the question items for EEB, the positive response for the question items of EIPLC were also high, with $91.7 \%$ agreeing or strongly agreeing with item A2, over $84 \%$ with items $\mathrm{A} 5$ and $\mathrm{A} 6$, and over $75 \%$ with item A7. The findings of positive attitudes indicate that local residents held very high expectations for post-earthquake nature-based tourism development and believed that it could bring economic benefits to Wolong. They also acknowledged that they could gain individual benefits through the improvement of their living conditions.

In terms of local residents' attitudes towards the negative influences of post-earthquake nature-based tourism development, two constructs-EPP and EDPLC—scored 3.49 and 2.78 out of 5, respectively, suggesting that most local residents disagreed that development would cause substantial negative influences on the local economy and on their living conditions. The respondents particularly disagreed with the question items for the EDPLC construct, as over $40 \%$ of the respondents disagreed and strongly disagreed with four of the question items; the mean scores of all six items under EDPLC ranged from 2.38 to 3.05 , indicating that local residents generally disagreed that development would significantly negatively influence their living conditions.

Regarding the question items measuring local residents' support for development (see Table 3), the mean score for the proposed construct Support for Nature-based Tourism Development (SNBTD) was 4.58 of 5 , suggesting that local residents were willing to support development. Highly positive responses for all four question items in this construct were noted: over $90 \%$ of respondents agreed or strongly agreed with three of the four question items, and the mean scores for all these question items ranged from 4.49 to 4.81 out of 5 implying that they strongly supported the development. 
Table 2. Residents' expected attitudes towards post-earthquake nature-based tourism development in the Wolong National Nature Reserve.

\begin{tabular}{|c|c|c|c|c|c|c|c|c|c|c|c|}
\hline & Attitude Statements & SD (\%) & $\mathrm{D}(\%)$ & $\mathrm{N}(\%)$ & A (\%) & SA (\%) & Mean & $\begin{array}{c}\text { Std. } \\
\text { Deviation }\end{array}$ & $\begin{array}{c}\text { Factor } \\
\text { Loadings }\end{array}$ & $\begin{array}{l}\text { Average Variance } \\
\text { Extracted }\end{array}$ & $\begin{array}{l}\text { Composite } \\
\text { Reliability }\end{array}$ \\
\hline \multicolumn{2}{|r|}{ Expected economic benefits (EEB) } & & & & & & 4.58 & & & 0.72 & 0.868 \\
\hline A1 & $\begin{array}{l}\text { Nature-based tourism development will promote economic } \\
\text { development. }\end{array}$ & 1.3 & 1.6 & 2.2 & 19.9 & 74.9 & 4.66 & 0.73 & 0.629 & & \\
\hline A3 & $\begin{array}{l}\text { Nature-based tourism development will create employment } \\
\text { opportunities. }\end{array}$ & 0.5 & 2.4 & 6.2 & 23.3 & 67.5 & 4.55 & 0.77 & 0.780 & & \\
\hline A4 & Nature-based tourism development will generate tourism income. & 0.8 & 2.2 & 6.8 & 24.9 & 65.3 & 4.52 & 0.78 & 0.779 & & \\
\hline \multicolumn{2}{|r|}{ Expected improvement of personal living condition (EIPLC) } & & & & & & 4.33 & & & 0.58 & 0.810 \\
\hline $\mathrm{A} 2$ & $\begin{array}{l}\text { Nature-based tourism development will improve infrastructures of my } \\
\text { living place. }\end{array}$ & 0.5 & 1.1 & 6.8 & 22.2 & 69.5 & 4.59 & 0.71 & 0.710 & & \\
\hline A5 & $\begin{array}{l}\text { Nature-based tourism development will improve public facilities of my } \\
\text { living place }\end{array}$ & 0.5 & 3.3 & 11.1 & 32.6 & 52.4 & 4.33 & 0.84 & 0.539 & & \\
\hline A6 & $\begin{array}{l}\text { Nature-based tourism development will enhance my chance for cultural } \\
\text { exchange. }\end{array}$ & 0.5 & 2.7 & 12.3 & 34.5 & 49.9 & 4.30 & 0.83 & 0.533 & & \\
\hline A7 & $\begin{array}{l}\text { Nature-based tourism development will contribute to environmental } \\
\text { conservation of my community. }\end{array}$ & 2.2 & 5.2 & 17.2 & 31.4 & 44.0 & 4.10 & 1.01 & 0.482 & & \\
\hline \multicolumn{2}{|c|}{ Degradation of living environment (EDPLC) } & & & & & & 2.78 & & & 0.68 & 0.823 \\
\hline A9 & $\begin{array}{l}\text { Nature-based tourism development will cause excessive traffic } \\
\text { congestion of my living community. }\end{array}$ & 12.9 & 26.4 & 19.8 & 25.0 & 3.05 & 1.29 & 15.9 & 0.309 & & \\
\hline $\mathrm{A} 12$ & $\begin{array}{l}\text { Nature-based tourism development will cause conflicts between local } \\
\text { residents and tourists in my living community. }\end{array}$ & 17.4 & 21.5 & 30.2 & 19.6 & 2.86 & 1.24 & 11.4 & 0.517 & & \\
\hline A13 & $\begin{array}{l}\text { Nature-based tourism development will increase environmental } \\
\text { pollution of my living community. }\end{array}$ & 17.9 & 24.1 & 16.5 & 26.6 & 2.96 & 1.35 & 14.9 & 0.556 & & \\
\hline A14 & Nature-based tourism development will disturb my daily life. & 28.1 & 32.8 & 20.1 & 10.7 & 2.38 & 1.23 & 8.3 & 0.382 & & \\
\hline A15 & $\begin{array}{l}\text { Nature-based tourism development will increase } \\
\text { crime/robberies/vandalism in my community. }\end{array}$ & 26.1 & 26.4 & 24.7 & 15.8 & 2.51 & 1.23 & 7.1 & 0.727 & & \\
\hline A16 & $\begin{array}{l}\text { Nature-based tourism development will cause social problems including } \\
\text { alcoholic, squander that negatively affect in my living community. }\end{array}$ & 16.5 & 29.2 & 22.6 & 18.2 & 2.83 & 1.28 & 13.5 & 0.666 & & \\
\hline \multicolumn{2}{|c|}{ Expected economic pressures (EEP) } & & & & & & 3.49 & & & 0.54 & 0.778 \\
\hline A8 & $\begin{array}{l}\text { Nature-based tourism development will result in uniformity of } \\
\text { economic structure. }\end{array}$ & 7.7 & 16.4 & 32.6 & 23.3 & 3.32 & 1.19 & 20.0 & 0.284 & & \\
\hline A10 & Nature-based tourism development will increase real estate cost. & 6.3 & 11.1 & 27.4 & 29.1 & 3.58 & 1.17 & 26.1 & 0.678 & & \\
\hline A11 & $\begin{array}{l}\text { Nature-based tourism development will increase price of goods and } \\
\text { services. }\end{array}$ & 4.7 & 15.5 & 23.8 & 30.1 & 3.57 & 1.17 & 26.0 & 0.634 & & \\
\hline
\end{tabular}

Notes: 1 represents strongly disagree (SD) and 5 means strongly agree (SA). 
Table 3. Local residents' support for nature-based tourism development in the Wolong National Nature Reserve.

\begin{tabular}{|c|c|c|c|c|c|c|c|c|c|c|c|}
\hline & Behavior Statements & SD (\%) & $\mathrm{D}(\%)$ & $\mathbf{N}(\%)$ & A $(\%)$ & SA $(\%)$ & Mean & $\begin{array}{c}\text { Std. } \\
\text { Deviation }\end{array}$ & $\begin{array}{l}\text { Factor } \\
\text { Loadings }\end{array}$ & $\begin{array}{l}\text { Average Variance } \\
\text { Extracted }\end{array}$ & $\begin{array}{l}\text { Composite } \\
\text { Reliability }\end{array}$ \\
\hline \multicolumn{2}{|c|}{ Support for nature-based tourism development (SNBTD) } & & & & & & 4.58 & & & 0.74 & 0.861 \\
\hline B1 & I prefer more tourists to visit Wolong. & 0.5 & 1.6 & 2.4 & 7.5 & 87.9 & 4.81 & 0.61 & 0.605 & & \\
\hline B2 & I am happy to interact with tourists. & 1.1 & 1.6 & 2.5 & 13.6 & 81.2 & 4.72 & 0.69 & 0.749 & & \\
\hline B3 & $\begin{array}{l}\text { I prefer members of my household working in } \\
\text { the nature-based tourism industry. }\end{array}$ & 0.5 & 0.8 & 2.5 & 16.6 & 79.6 & 4.74 & 0.60 & 0.845 & & \\
\hline B4 & $\begin{array}{l}\text { I prefer to be involved in the decision making } \\
\text { process of the nature-based tourism } \\
\text { development. }\end{array}$ & 1.4 & 4.1 & 6.3 & 20.7 & 67.7 & 4.49 & 0.89 & 0.568 & & \\
\hline
\end{tabular}

Notes: 1 represents strongly disagree (SD) and 5 means strongly agree (SA). 
The reliability of all constructs ranged from 0.778 to 0.868 , suggesting that all the proposed constructs are highly reliable; therefore, they were used for further analysis.

\subsection{Structural Relationships between Key Variables}

The measurement model specified how the latent variables should be assessed in terms of the observed variables and the validity and reliability of the responses to the observed variables and the latent variables were represented (Figure 3). A confirmatory factor analysis (CFA) and SEM were used to test the proposed conceptual model of the association between the constructs proposed in Figure 1. The CFA results indicated that the $\chi^{2}$ of the measurement model was 417.847, with 160 degrees of freedom $(d f)(p<0.01)$; therefore, the $\chi^{2} / d f$ value was less than 5.0, implying that the measurement model has good fit with the data.

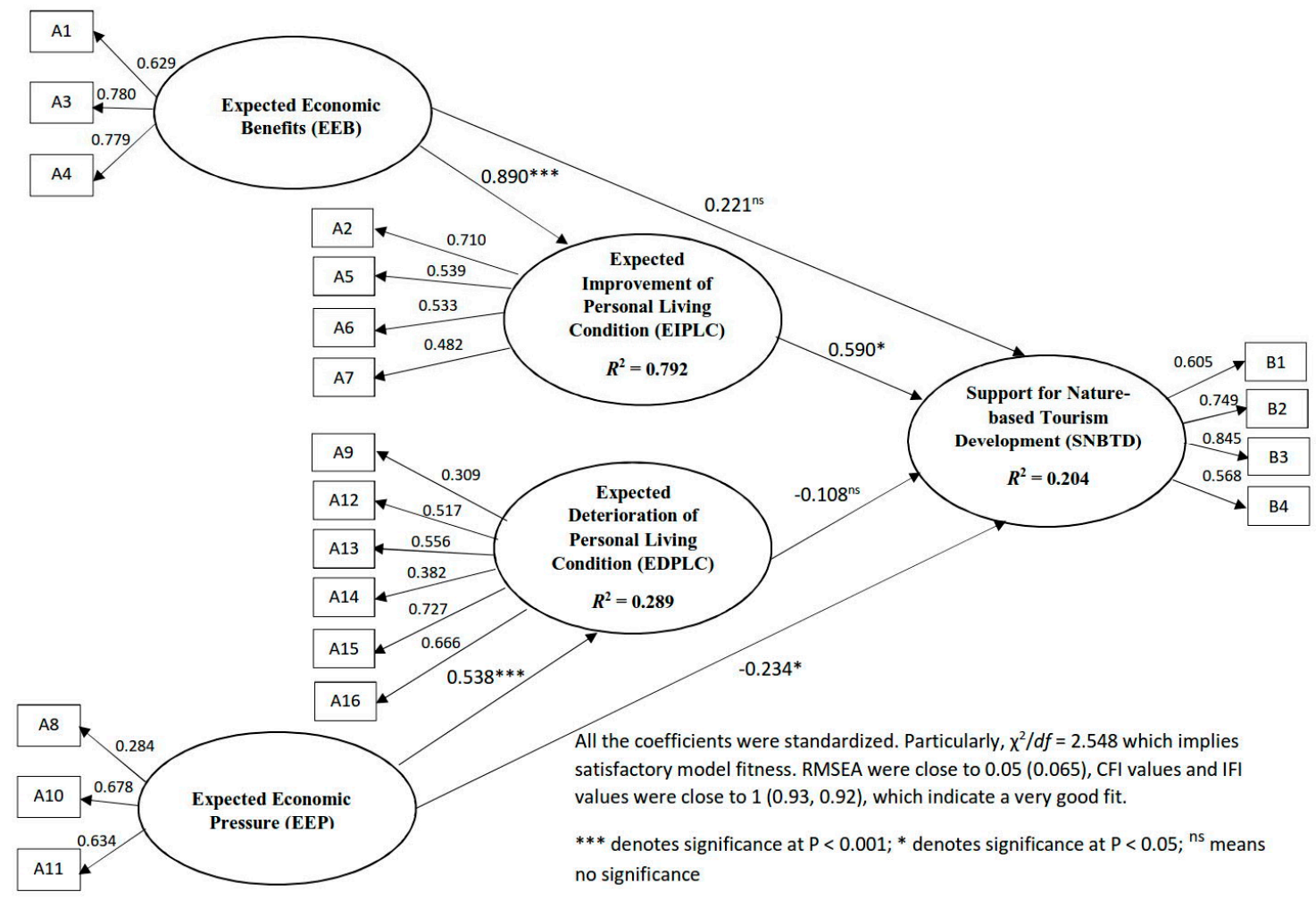

Figure 3. Structural model of the residents' attitudes and supports for nature-based tourism development.

Other measurement model fit indices were also tested to justify the model fitness. According to a general rule for model fit, the root mean square error of approximation (RMSEA) should be close to 0.05 , the comparative fit index (CFI) should exceed 0.90, and the increment fit index (IFI) should exceed 0.90 . Our model achieved an RMSEA value of 0.065 , a CFI of 0.93 and an IFI of 0.92 , all near the threshold values.

Figure 4 presents the results of the structural modelling in a path diagram that illustrates the linear relationships among the EEB, EEP, EIPLC, EDPLC, and SNBTD constructs. The diagram indicates that EEB was positively correlated with EIPEC but does not suggest a significant relationship with SNBDT, implying that residents' expected economic benefit does not directly lead to their support for nature-based tourism development in the Wolong National Nature Reserve. However, EIPLC had a significant positive correlation with SNBTD, meaning that residents' EIPLC is a significant predictor of their support for development. In contrast, the path diagram suggests that EEP was positively correlated with EDPLC and SNBTD, implying that residents believed that the expected 
economic pressure caused by development would affect their personal living conditions, which led to unsupportive attitudes. Surprisingly, EDPLC did not have a significant relationship with SNBTD, meaning that EDPLC is not a significant predictor of residents' supportiveness for development. The path analysis suggests that EIPLC played a mediating role in the relationship between EEB and SNBTD, while EDPLC did not. In summary, four (H2, H3, H5, and H6) of the six proposed hypotheses were supported, and two ( $\mathrm{H} 1$ and $\mathrm{H} 4)$ were not. In addition, the square multiple correlation (equivalent to R2) was 0.204 , suggesting that $20.4 \%$ of the variance in SNBTD can be attributed to all other constructs.

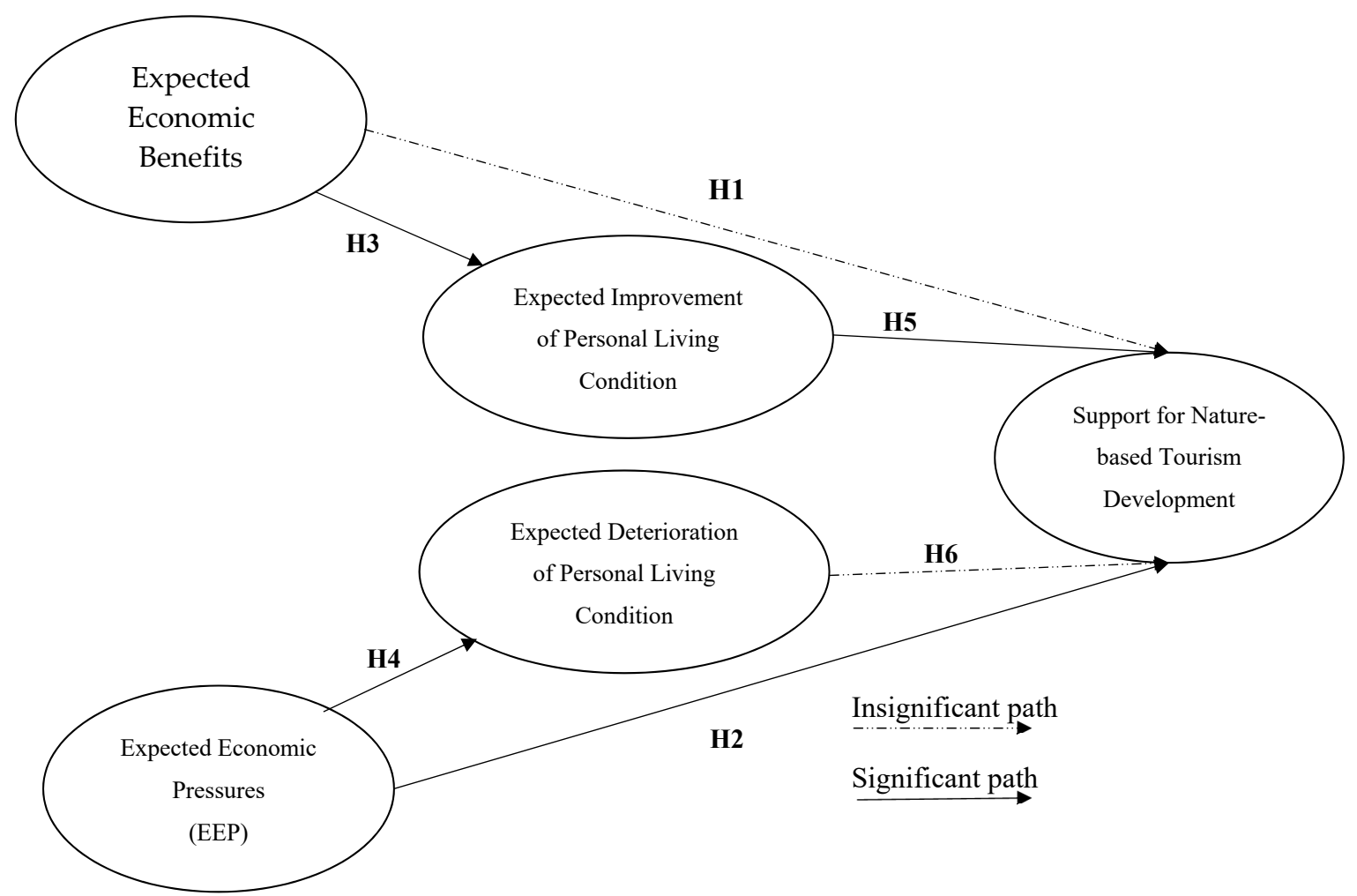

Figure 4. Observed relationships between local residents' expected attitudes and support for the post-earthquake nature-based tourism development in the Wolong National Nature Reserve.

\section{Discussion and Conclusions}

The findings of our study reported that the local residents of the Wolong National Nature Reserve held high expectations for post-earthquake nature-based tourism development, as they expected that development could provide economic benefits and improve their individual living conditions [65]. Similar findings were generally reported by previous studies $[27,30]$. The economic hardship and decreased living conditions due to the substantial reduction in their income after the earthquake contributed to local residents' desire for tourism development. They believed that nature-based tourism development could pull them out of this difficult situation, which could explain their high expectations for post-earthquake nature-based tourism development. Moreover, given such a prolonged period of difficult living and financial situations for local residents, local authorities may have given an optimistic view of nature-based tourism development to encourage local residents to support it [24]; with this support, the local authorities could more easily implement a developmental plan, as actions need to be taken during the development phase, such as land resumption [22]. However, extremely high expectations of the local residents regarding the economic benefits of development may impose tremendous pressure on the local authorities, who may adopt a rather unsustainable method for development to maximize the number of visitors to the nature reserve. This approach-without 
effective strategies to manage and control visitor numbers-could cause irreversible negative impacts on the local community and environment.

An important finding of our study is that residents' expected economic benefits of post-earthquake nature-based tourism development in the Wolong National Nature Reserve did not necessarily lead to their support for it. This contradicts findings of some other studies, which report that residents would support tourism development if they believed or expected that it would be able to provide them benefits, particularly community economic benefits $[18,39]$. This is not the case in our study; generic economic benefits, such as increased employment opportunities, promotion of economic development and the provision of income to the community, are not the most important aspects that encourage local residents to support development. The finding from this study reveals that the expected improvement of personal living condition is a useful mediator for predicting residents' support for nature-based tourism development.

One possible reason is that they do not believe that these benefits will be realized, due to a lack of trust in the government or in the developers $[53,66]$. There have been cases in China in which local residents received unfair distribution of economic benefits from development, particularly affecting their personal livelihoods and failing to meet their expectations [67]. Therefore, residents tend to be concerned about their own benefits to determine whether they should support development [18]. Previous experience with economic leakage of tourism development projects in different parts of China [68] may have led local residents to lack confidence in the achievement of real benefits from development [69] and therefore their hesitation to support development, even though they may be confident that post-earthquake nature-based tourism development could bring economic benefits to Wolong and thus improve their economic conditions. Current post-earthquake nature-based tourism development in the Wolong National Nature Reserve relies heavily on non-local tourism developers, which may trigger concern among local residents that they may not eventually benefit from development. Therefore, "seeing is believing" is important for residents' support for nature-based tourism development. If the expected economic benefits from nature-based tourism can help to improve personal living condition, residents tend to support for the tourism development. The findings are consistent with some recent studies, which all indicated that more concerns should be given to non-economic benefits or high-order needs $[43,53,57]$.

Consistent with previous research, our study suggested a significant negative correlation between residents' expected economic pressure and their support for nature-based tourism development [34,35]. Moreover, EEP is a significant predictor of EDPLC. Unlike EIPLC, EDPLC does not act as a mediator and serves as a significant predictor of SNBTD. Expected adverse impacts on their own living conditions did not necessarily determine local residents' supportiveness. In this case, "seeing is believing" is not necessarily an important consideration. This finding makes real sense, as residents who believe development will cause negative economic impacts would not directly support development and thus would not need to see its real impacts before making a support decision. Therefore, EDPLC did not play a mediating role in predicting supportiveness for nature-based tourism development.

Understanding local residents' attitudes towards tourism development has been an important research topic in tourism studies, as this information is useful for assessing the obstacles to or opportunities of the proposed tourism development. Local authorities or developers are highly interested in knowing the views of the local community to gain support by adjusting their planning [70]. A bottom-up approach or community-based approach to nature-based tourism development in which the local community's opinions are considered is common in some destinations. However, a top-down approach that neglects the opinions of the local community has also been implemented by many less developed countries such as China, potentially causing conflicts between tourists, developers, local governments and local residents. Although the bottom-up approach to tourism development projects is not very common in China, local authorities in the Wolong National Nature Reserve tend to solicit opinions from the local community for nature-based tourism development. Building harmony 
in a nature-based destination by considering various opinions, including those of environmentalists, is important to not only reduce the possibility of conflicts between the various parties but also to control over-development, particularly in an ecologically sensitive destination such as the Wolong National Nature Reserve. The adoption of a sustainable approach for tourism development would be more favorable for a nature reserve, and designing a mechanism to ensure local residents benefit from the tourism development is a vital task for the local government. Implementing a sustainable tourism development framework and mechanism such as implementation of sustainable tourism certification or accreditation systems can be an option for the local authority to monitor the tourism industry, avoiding environmental pollution and economic leakage. Local residents' benefits can also be ensured through the implementation of such monitoring system if regulating indicators (employment policy, purchasing policy etc.) have been included in the certification system that the tourism businesses need to be compliance to such indicators.

Our current study has successfully explored the association between local residents' expected attitudes towards nature-based tourism development and how residents' expected attitudes affect their support for development. However, our study has limitations, as the questionnaire survey may not fully address the opinions and comments of local residents on nature-based tourism development in the Wolong National Nature Reserve: most question items were pre-designed, and further opinions and comments of the local residents could not be recorded, which may have distorted residents' attitudes towards development. Further in-depth interviews could glean more qualitative comments from the respondents to further understand their views and comments on development. Therefore, qualitative research on the attitudes of Wolong's residents would be useful for further understanding their concerns. In addition, a further study to investigate Wolong's residents' attitudes a few years after development would be interesting. Such research could allow a comparison of the differences in residents' expected attitudes towards nature-based tourism development before development and their perceived attitudes after development, illustrating whether development met their expectations.

Acknowledgments: The authors wish to acknowledge the support offered by the Wolong Special Administration Region for the data collection in Wolong, Sichuan and are grateful to the Trust Fund in Support of Reconstruction in the Sichuan Earthquake Stricken Areas of the Development Bureau of Hong Kong SAR Government, for providing funding support to this research project.

Author Contributions: Shuwen Liu carried out the field work, analysed the data and drafted the manuscript; Lewis Cheung and Alex Lo analysed the field data and drafted the manuscript; Wei Fang carried out the field work and drafted the manuscript.

Conflicts of Interest: The authors declare no conflict of interest.

\section{Appendix A. Questionnaire Survey of Wolong National Nature Reserve}

\section{Part I. Residents' Attitudes towards Nature-Based Tourism Development in the Wolong National Nature Reserve}

The following statements are related to attitudes towards tourism development at Wolong. For each statement below, please indicate whether you strongly disagree (SD), mildly disagree (MD), unsure (U), mildly agree (MA) or strongly agree (SA) with it. 


\begin{tabular}{|c|c|c|c|c|c|c|}
\hline Statement & & SD & MD & $\mathbf{U}$ & MA & SA \\
\hline 1 & Nature-based tourism development will promote economic development. & & & & & \\
\hline 2 & $\begin{array}{l}\text { Nature-based tourism development will improve infrastructures of my } \\
\text { living place. }\end{array}$ & & & & & \\
\hline 3 & $\begin{array}{l}\text { Nature-based tourism development will create employment } \\
\text { opportunities. }\end{array}$ & & & & & \\
\hline 4 & Nature-based tourism development will generate tourism income. & & & & & \\
\hline 5 & $\begin{array}{l}\text { Nature-based tourism development will improve public facilities of my } \\
\text { living place }\end{array}$ & & & & & \\
\hline 6 & $\begin{array}{l}\text { Nature-based tourism development will enhance my chance for cultural } \\
\text { exchange. }\end{array}$ & & & & & \\
\hline 7 & $\begin{array}{l}\text { Nature-based tourism development will contribute to environmental } \\
\text { conservation of my community. }\end{array}$ & & & & & \\
\hline 8 & $\begin{array}{l}\text { Nature-based tourism development will result in uniformity of economic } \\
\text { structure. }\end{array}$ & & & & & \\
\hline 9 & $\begin{array}{l}\text { Nature-based tourism development will cause excessive traffic congestion } \\
\text { of my living community. }\end{array}$ & & & & & \\
\hline 10 & Nature-based tourism development will increase real estate cost. & & & & & \\
\hline 11 & $\begin{array}{l}\text { Nature-based tourism development will increase price of goods and } \\
\text { services. }\end{array}$ & & & & & \\
\hline 12 & $\begin{array}{l}\text { Nature-based tourism development will cause conflicts between local } \\
\text { residents and tourists in my living community. }\end{array}$ & & & & & \\
\hline 13 & $\begin{array}{l}\text { Nature-based tourism development will increase environmental pollution } \\
\text { of my living community. }\end{array}$ & & & & & \\
\hline 14 & Nature-based tourism development will disturb my daily life. & & & & & \\
\hline 15 & $\begin{array}{l}\text { Nature-based tourism development will increase } \\
\text { crime/robberies/vandalism in my community. }\end{array}$ & & & & & \\
\hline 16 & $\begin{array}{l}\text { Nature-based tourism development will cause social problems including } \\
\text { alcoholic, squander that negatively affect in my living community. }\end{array}$ & & & & & \\
\hline
\end{tabular}

Part II. Willingness to Support for Nature-Based Tourism Development in the Wolong National Nature Reserve

\begin{tabular}{|c|c|c|c|c|c|c|}
\hline Statement & & SD & MD & $\mathbf{U}$ & MA & SA \\
\hline 1 & I prefer more tourists to visit Wolong. & & & & & \\
\hline 2 & I am happy to interact with tourists. & & & & & \\
\hline 3 & $\begin{array}{l}\text { I prefer members of my household working in the } \\
\text { nature-based tourism industry. }\end{array}$ & & & & & \\
\hline 4 & $\begin{array}{l}\text { I prefer to be involved in the decision making process } \\
\text { of the nature-based tourism development. }\end{array}$ & & & & & \\
\hline
\end{tabular}


Part III. Socio-Demographic Information

\begin{tabular}{ll}
\hline Gender & $\square \mathbf{M} \square \mathbf{F}$ \\
\hline Age & $\square$ 15-24 $\square$ 25-34 $\square$ 35-44 $\square$ 45-54 $\square 55-64$ \\
& $\square 65$ or above \\
\hline \multirow{2}{*}{ Education background } & $\square$ Primary school or no education $\square$ Junior secondary school \\
& $\square$ Senior secondary education $\square$ Post-secondary education \\
& $\square$ Bachelor degree $\square$ Master degree or above \\
\hline Ethnic groups & $\square$ Han $\square$ Zang $\square$ Qiang $\square$ Others \\
\hline Monthly Salary & $\square$ No Income $\square$ Below RMB 499 $\square$ RMB 500-999 $\square$ RMB 1000-1499 \\
& $\square$ RMB 1500-1999 $\square$ RMB 2000-2499 $\square$ RMB 2500-2999 \\
& $\square$ RMB 3000 or above \\
& $\square$ Agriculture \\
& $\square$ Commercial business \\
& $\square$ Government officer \\
& $\square$ Teacher \\
& $\square$ Unemployed \\
& $\square$ Retired \\
& $\square$ Others
\end{tabular}

Questionnaire completed. Thank you for your participation!

\section{References}

1. Iorio, M.; Corsale, A. Rural tourism and livelihood strategies in Romania. J. Rural Stud. 2010, 26, $152-162$. [CrossRef]

2. Chow, A.S.Y.; Cheng, I.N.Y.; Cheung, L.T.O. Self-determined travel motivations and ecologically responsible attitudes of nature-based visitors to the Ramsar wetland in South China. Ann. Leis. Res. 2017, 25, 1-20. [CrossRef]

3. Lo, A.Y.; Cheung, L.T.O.; Lee, A.K.-Y.; Xu, B. Confidence and trust in public institution natural hazards management: Case studies in urban and rural china. Prof. Geogr. 2016, 68, 475-484. [CrossRef]

4. Henly-Shepard, S.; Anderson, C.; Burnett, K.; Cox, L.J.; Kittinger, J.N.; Ka' aumoana, M.A. Quantifying household social resilience: A place-based approach in a rapidly transforming community. Nat. Hazards 2015, 75, 343-363. [CrossRef]

5. Shao, Y.; Xu, J. Regulating post-disaster reconstruction planning in china: Towards a resilience-based approach? Asian Geogr. 2017, 34, 71-89. [CrossRef]

6. Abramson, D.; Qi, Y. Urban-rural integration in the earthquake zone: Sichuan's post-disaster reconstruction and the expansion of the Chengdu metropole. Pac. Aff. 2011, 84, 495-523. [CrossRef]

7. Yang, Z.; Chun, Z.; William, D.; Robert, O. Planning and recovery following the great 1976 Tangshan earthquake. J. Plan. Hist. 2015, 14, 224-243.

8. Regmi, K.D. The political economy of 2015 Nepal earthquake: Some critical reflections. Asian Geogr. 2016, 33, 77-96. [CrossRef]

9. Hayat, E.; Amaratunga, D. The role of local government in post-disaster road reconstruction: Assessment of factors affecting local government road maintenance capacity. In Disaster Risk Reduction in Indonesia: Progress, Challenges, and Issues; Djalante, R., Garschagen, M., Thomalla, F., Shaw, R., Eds.; Springer International Publishing: Cham, Switzerland, 2017; pp. 255-279.

10. Tsai, C.-H.; Wu, T.-C.; Wall, G.; Linliu, S.-C. Perceptions of tourism impacts and community resilience to natural disasters. Tour. Geogr. 2016, 18, 152-173. [CrossRef]

11. Boon, H.J. Disaster resilience in a flood-impacted rural Australian town. Nat. Hazards 2014, 71, 683-701. [CrossRef]

12. Kapucu, N. Collaborative emergency management: Better community organising, better public preparedness and response. Disasters 2008, 32, 239-262. [CrossRef] [PubMed] 
13. Faulkner, B.; Vikulov, S. Katherine, washed out one day, back on track the next: A post-mortem of a tourism disaster. Tour. Manag. 2001, 22, 331-344. [CrossRef]

14. Huang, J.-H.; Min, J.C.H. Earthquake devastation and recovery in tourism: The Taiwan case. Tour. Manag. 2002, 23, 145-154. [CrossRef]

15. Biran, A.; Liu, W.; Li, G.; Eichhorn, V. Consuming post-disaster destinations: The case of Sichuan, China. Ann. Tour. Res. 2014, 47,1-17. [CrossRef]

16. Mak, B.; Cheung, L.; Hui, D. Community participation in the decision-making process for sustainable tourism development in rural areas of Hong Kong, China. Sustainability 2017, 9, 1695. [CrossRef]

17. Nunkoo, R.; So, K.K.F. Residents' support for tourism: Testing alternative structural models. J. Travel Res. 2016, 55, 847-861. [CrossRef]

18. Boley, B.B.; McGehee, N.G.; Perdue, R.R.; Long, P. Empowerment and resident attitudes toward tourism: Strengthening the theoretical foundation through a Weberian lens. Ann. Tour. Res. 2014, 49, 33-50. [CrossRef]

19. Lo, A.Y.; Cheung, L.T.O. Geographies of social capital: Catastrophe experience, risk perception, and the transformation of social space in postearthquake resettlements in Sichuan, China. Ann. Am. Assoc. Geogr. 2016, 106, 874-890. [CrossRef]

20. Ap, J. Residents' perceptions on tourism impacts. Ann. Tour. Res. 1992, 19, 665-690. [CrossRef]

21. Sirakaya, E.; Teye, V.; Sonmez, S. Understanding residents' support for tourism development in the central region of Ghana. J. Travel Res. 2002, 41, 57-67. [CrossRef]

22. Harrill, R. Residents' attitudes toward tourism development: A literature review with implications for tourism planning. J. Plan. Lit. 2004, 18, 251-266. [CrossRef]

23. World Tourism Organization (WTO). Indicators of Sustainable Development for Tourism Destination: A Guidebook; World Tourism Organization: Madrid, Spain, 2004.

24. Stylidis, D.; Terzidou, M. Tourism and the economic crisis in Kavala, Greece. Ann. Tour. Res. 2014, 44, 210-226. [CrossRef]

25. Ritchie, B.W.; Inkari, M. Host community attitudes toward tourism and cultural tourism development: The case of the Lewes district, southern England. Int. J. Tour. Res. 2006, 8, 27-44. [CrossRef]

26. Vargas-Sánchez, A.; Plaza-Mejía, M.D.L.Á.; Porras-Bueno, N. Understanding residents' attitudes toward the development of industrial tourism in a former mining community. J. Travel Res. 2009, 47, 373-387. [CrossRef]

27. Andereck, K.L.; Vogt, C.A. The relationship between residents' attitudes toward tourism and tourism development options. J. Travel Res. 2000, 39, 27-36. [CrossRef]

28. Liu, J.C.; Var, T. Resident attitudes toward tourism impacts in Hawaii. Ann. Tour. Res. 1986, 13, $193-214$. [CrossRef]

29. Mehta, J.N.; Kellert, S.R. Local attitudes toward community-based conservation policy and programmes in Nepal: A case study in the Makalu-Barun conservation area. Environ. Conserv. 1998, 25, 320-333. [CrossRef]

30. Lai, P.-H.; Nepal, S.K. Local perspectives of ecotourism development in Tawushan Nature Reserve, Taiwan. Tour. Manag. 2006, 27, 1117-1129. [CrossRef]

31. Smith, M.; Krannich, R. Tourism dependence and resident attitudes. Ann. Tour. Res. 1998, 25, $783-802$. [CrossRef]

32. Lankford, S.V. Attitudes and perceptions toward tourism and rural regional development. J. Travel Res. 1994, 32, 35-43. [CrossRef]

33. Snaith, T.; Haley, A. Residents' opinions of tourism development in the historic city of York, England. Tour. Manag. 1999, 20, 595-603. [CrossRef]

34. McGehee, N.G.; Andereck, K.L. Factors predicting rural residents' support of tourism. J. Travel Res. 2004, 43, 131-140. [CrossRef]

35. Bujosa, A.; Rosselló, J. Modelling environmental attitudes toward tourism. Tour. Manag. 2007, 28 , 688-695. [CrossRef]

36. Saveriades, A. Establishing the social tourism carrying capacity for the tourist resorts of the east coast of the republic of Cyprus. Tour. Manag. 2000, 21, 147-156. [CrossRef]

37. Látková, P.; Vogt, C.A. Residents' attitudes toward existing and future tourism development in rural communities. J. Travel Res. 2012, 51, 50-67. [CrossRef]

38. Gursoy, D.; Jurowski, C.; Uysal, M. Resident attitudes: A structural modeling approach. Ann. Tour. Res. 2002, 29, 79-105. [CrossRef] 
39. Andereck, K.L.; McGehee, N.G. The attitudes of community residents towards tourism. In Tourism, Recreation and Sustainability: Linking Culture $\mathcal{E}$ the Environment, 2nd ed.; McCool, S.F., Moisey, R.N., Eds.; CABI: Cambridge, UK, 2009; pp. 236-259.

40. Jurowski, C.; Uysal, M.; Williams, D.R. A theoretical analysis of host community resident reactions to tourism. J. Travel Res. 1997, 36, 3-11. [CrossRef]

41. Deccio, C.; Baloglu, S. Nonhost community resident reactions to the 2002 winter Olympics: The spillover impacts. J. Travel Res. 2002, 41, 46-56. [CrossRef]

42. Woosnam, K.M.; Norman, W.C.; Ying, T. Exploring the theoretical framework of emotional solidarity between residents and tourists. J. Travel Res. 2009, 48, 245-258. [CrossRef]

43. Schofield, P. City resident attitudes to proposed tourism development and its impacts on the community. Int. J. Tour. Res. 2011, 13, 218-233. [CrossRef]

44. Tomljenovic, R.; Faulkner, B. Tourism and older residents in a Sunbelt resort. Ann. Tour. Res. 2000, $27,93-114$. [CrossRef]

45. Andereck, K.L.; Nyaupane, G.P. Exploring the nature of tourism and quality of life perceptions among residents. J. Travel Res. 2011, 50, 248-260. [CrossRef]

46. Kaplanidou, K.; Karadakis, K.; Gibson, H.; Thapa, B.; Walker, M.; Geldenhuys, S.; Coetzee, W. Quality of life, event impacts, and mega-event support among south African residents before and after the 2010 FIFA world cup. J. Travel Res. 2013, 52, 631-645. [CrossRef]

47. Jeon, M.M.; Kang, M.; Desmarais, E. Residents' perceived quality of life in a cultural-heritage tourism destination. Appl. Res. Qual. Life 2014, 11, 105-123. [CrossRef]

48. Uysal, M.; Perdue, R.; Sirgy, R. Handbook of Tourism and Quality-of-Life Research: Enhancing the Lives of Tourists and Residents of Host Communities; Springer: Dordrecht, The Netherlands; New York, NY, USA, 2012.

49. Zhuang, X.; Zhu, H.; Deng, S. Institutional ethical analysis of resident perceptions of tourism in two Chinese villages. Tour. Geogr. 2014, 16, 785-798.

50. Tovar, C.; Lockwood, M. Social impacts of tourism: An Australian regional case study. Int. J. Tour. Res. 2008, 10, 365-378. [CrossRef]

51. Stronza, A.; Gordillo, J. Community views of ecotourism. Ann. Tour. Res. 2008, 35, 448-468. [CrossRef]

52. Dyer, P.; Gursoy, D.; Sharma, B.; Carter, J. Structural modeling of resident perceptions of tourism and associated development on the sunshine coast, Australia. Tour. Manag. 2007, 28, 409-422. [CrossRef]

53. Nunkoo, R.; Ramkissoon, H. Developing a community support model for tourism. Ann. Tour. Res. 2011, 38, 964-988. [CrossRef]

54. Cummins, R.A. The domains of life satisfaction: An attempt to order chaos. Soc. Indic. Res. 1997, 38, $303-328$. [CrossRef]

55. Nunkoo, R.; Ramkissoon, H. Modeling community support for a proposed integrated resort project. J. Sustain. Tour. 2009, 18, 257-277. [CrossRef]

56. Ko, D.-W.; Stewart, W.P. A structural equation model of residents' attitudes for tourism development. Tour. Manag. 2002, 23, 521-530. [CrossRef]

57. Woo, E.; Kim, H.; Uysal, M. Life satisfaction and support for tourism development. Ann. Tour. Res. 2015, 50, 84-97. [CrossRef]

58. Liu, S.; Cheng, I.; Cheung, L. The roles of formal and informal institutions in small tourism business development in rural areas of South China. Sustainability 2017, 9, 1194. [CrossRef]

59. Liu, S.; Cheung, L.T.O. Sense of place and tourism business development. Tour. Geogr. 2016, 18, $174-193$. [CrossRef]

60. Liu, W.; Vogt, C.A.; Lupi, F.; He, G.; Ouyang, Z.; Liu, J. Evolution of tourism in a flagship protected area of china. J. Sustain. Tour. 2016, 24, 203-226. [CrossRef]

61. Cui, P.; Chen, X.-Q.; Zhu, Y.-Y.; Su, F.-H.; Wei, F.-Q.; Han, Y.-S.; Liu, H.-J.; Zhuang, J.-Q. The Wenchuan earthquake (May 12, 2008), Sichuan province, China, and resulting geohazards. Nat. Hazards 2011, 56, $19-36$. [CrossRef]

62. Lo, A.Y.; Cheung, L.T.O. Seismic risk perception in the aftermath of Wenchuan earthquakes in southwestern china. Nat. Hazards 2015, 78, 1979-1996. [CrossRef]

63. Mbaiwa, J.E.; Stronza, A.L. Changes in resident attitudes towards tourism development and conservation in the Okavango delta, Botswana. J. Environ. Manag. 2011, 92, 1950-1959. [CrossRef] [PubMed] 
64. Teye, V.; Sirakaya, E.; Sönmez, S.F. Residents' attitudes toward tourism development. Ann. Tour. Res. 2002, 29, 668-688. [CrossRef]

65. Stone, M.; Wall, G. Ecotourism and community development: Case studies from Hainan, China. Environ. Manag. 2004, 33, 12-24. [CrossRef] [PubMed]

66. Nunkoo, R. Toward a more comprehensive use of social exchange theory to study residents' attitudes to tourism. Procedia Econ. Finance 2016, 39, 588-596. [CrossRef]

67. Xu, J.; Lü, Y.; Chen, L.; Liu, Y. Contribution of tourism development to protected area management: Local stakeholder perspectives. Int. J. Sustain. Dev. World Ecol. 2009, 16, 30-36. [CrossRef]

68. Zhong, L.; Deng, J.; Xiang, B. Tourism development and the tourism area life-cycle model: A case study of Zhangiiajie National Forest Park, China. Tour. Manag. 2008, 29, 841-856. [CrossRef]

69. He, G.; Chen, X.; Liu, W.; Bearer, S.; Zhou, S.; Cheng, L.Y.; Zhang, H.; Ouyang, Z.; Liu, J. Distribution of economic benefits from ecotourism: A case study of wolong nature reserve for giant pandas in China. Environ. Manag. 2008, 42, 1017-1025. [CrossRef] [PubMed]

70. Lo, A.Y.H.; Jim, C.Y. Citizen attitude and expectation towards greenspace provision in compact urban milieu. Land Use Policy 2012, 29, 577-586. [CrossRef]

(C) 2018 by the authors. Licensee MDPI, Basel, Switzerland. This article is an open access article distributed under the terms and conditions of the Creative Commons Attribution (CC BY) license (http:/ / creativecommons.org/licenses/by/4.0/). 